\title{
Huey P. Newton and the Radicalization of the Urban Poor
}

[Penultimate Draft; do not cite]

Huey P. Newton, founder of the Black Panther Party, is one of the most interesting and intriguing American intellectuals from the last half of the $20^{\text {th }}$ century. Despite that fact Newton has been ignored in main stream discussions of political philosophy. Newton's genius rested in his ability to amalgamate and synthesize others' thinking, and then reinterpreting and making it relevant to the situation that existed in the United States in his time, particularly for AfricanAmericans in the densely populated urban centers in the North and West. Newton saw himself continuing the Marxist-Leninist tradition and one of the most important aspects of his thought was his reinterpretation of Marxist class structure.

This paper presents Newton's position that it is the urban poor-who Newton identifies with the lumpenproletariat - who act as the revolutionary class that will bring about a change in the socio-economic order. To that end, there is first a discussion of Newton's view of the lumpenproletariat and how it differs from the traditional Marxist understanding. Then there is an explanation of the role of the vanguard and its relationship to the lumpenproletariat. The paper concludes with a comparison of Frantz Fanon's and Newton's understanding of the lumpenproletariat, and responds to the "problem of lumpenization" in the Black Panther Party.

This paper actually serves two purposes. Primarily its goal is to discuss Newton's ideas relating to the radicalization of the urban poor. However, this paper also seeks to simply bring a voice to the table that has too long been ignored. While the last decade has seen an increase in literature on Newton, very little of it has looked critically and philosophically at Newton's thought itself, generally, and his ideas regarding class, in particular.

Before continuing, I would like to quickly dismiss the argument that Newton is not relevant to a discussion of political philosophy. First, and most importantly, to suggest, for example, that Newton is a "crazed black radical" and therefore has nothing important to contribute to a serious philosophical debate is clearly a fallacious ad hominem argument. Second, it is important to note that "the Black Panther Party has written a chapter in the history

of American radicalism that ranks with the International Workers of the World (Wobblies),"1 and is thus quite politically relevant. Further, "Newton was, without a doubt, the most forceful, best-

\footnotetext{
${ }^{1}$ Jeffries, Judson. Huey P. Newton: The Radical Theorist. p. xvii.
} 
known and most ambitious theorist-practitioner of the Black Power Movement."2 Thus, it can be argued that as a historical fact Newton is relevant to, and deserving of, serious philosophical discussion. Finally, it should not be forgotten that Newton was an academic. In 1980, Newton received his Ph.D. from the University of California at Santa Cruz. ${ }^{3}$

Traditionally in Marxism, it was the proletariat that was viewed as the revolutionary class. Marx calls on the workers of the world to unite and take back the means of production: "The proletarians have nothing to lose but their chains. They have a world to win."4 However, on Newton's analysis the circumstances that existed for the proletariat to act as the revolutionary class were no longer present. Instead it was the lumpenproletariat who had nothing to lose.

Newton believed that the lumpenproletariat had the most revolutionary potential because they possessed qualities such as bravery, courage, and a nothing-to-lose attitude, whereas the proletariat was composed of working-class individuals with families and jobs and thus had much more to lose by waging a revolution. ${ }^{5}$

The rise of unions, among other factors, had created more security for the working-class. Thus, for Newton the most alienated and oppressed group were those who were unemployed or underemployed.

Another factor that made the lumpenproletariat the class to bring about change is that the class was growing. Advances in technology and increased automation were eliminating jobs for unskilled laborers. Only a small percentage of the original workforce would be necessary to run industry. Further, “[t]oday's capitalist has developed machinery to such a point that he can hire a group of specialized people called technocrats... and the technocrat [is] too specialized to be identified with the proletariat." 6 There were, therefore, two actions occurring. On the one hand, the total number of jobs was decreasing, and on the other hand, many of the jobs that did remain were so specialized as to exclude large portions of the former working-class. "Consequently, the majority of those considered proletarian would become the lumpenproletariat. And as these people became part of the lumpenproletariat, the more alienated they would feel."7

\footnotetext{
${ }^{2}$ McCartney, John. Black Power Ideologies: An Essay in African-American Thought. p. 133.

${ }^{3}$ Appiah, Kwame. Africana: The Encyclopedia of the African and African American Experience. p.1419.

${ }^{4}$ Marx, Karl and Fredrick Engels. Manifesto of the Communist Party. as found in Struik, Dirk. Birth of the Communist Manifesto. p. 125.

5 Jeffries. p. 15.

${ }^{6}$ To Die for the People. p. 29.

7 Jeffries. p. 14-5.
} 
Traditional Marxist analysis did not consider the lumpenproletariat at all beneficial in helping to bring about change in the overall structure of society. At best the lumpenproletariat may help, and at worst they could be used by those who control the means of production and social institutions to subvert the revolutionary potential of the proletariat. As Marx and Engels state in the Manifesto of the Communist Party, referring to the lumpenproletariat:

The "dangerous class," the social scum, that passively rotting mass thrown off by the lowest layers of the old society may here and there be swept into the movement by a proletarian revolution; its condition of life, however, prepare it far more for the part of a bribed tool of reactionary intrigue. ${ }^{8}$

Newton disagreed with Marx's analysis in a couple of ways. First, "[h]istory had taught Newton that the lumpenproletariat were full of enormous potential." 9 Second, Newton saw that social circumstances were such that Marx's understanding of the lumpenproletariat was no longer correct. Further, Newton had a broader view of the lumpenproletariat class than Marx did. Newton certainly included the unemployed and "social scum" in the lumpenproletariat, but he also viewed those who were underemployed or in the service industry as part of this class. Newton "envisioned a lumpen[proletariat] more akin to a sub-proletariat class devoid of the parasitical lifestyle associated with the traditional lumpen sector." ${ }^{10}$ Finally, Newton agreed with Mao Tsetung that the lumpenproletariat are "[b]rave fighters but apt to be destructive, they can become a revolutionary force if given proper guidance." 11

The guidance Newton was thinking about for the lumpenproletariat was not mere “armchair intellectualizing," or paternalistic in any sense. However, it did require a vanguard or cadre of professionals to act on the people's behalf and to help educate and raise their consciousness so they could better understand what was happening and clarify their needs.

Newton claimed that the Black Panther Party was "trying to build a political vehicle through which the people could express their revolutionary desires. We [the Black Panther Party] recognized that no party or organization can make the revolution, only the people can."12

\footnotetext{
${ }^{8}$ Marx. p. 100.

${ }^{9}$ Jeffries. p. 13-4.

${ }^{10}$ Jones, Charles and Judson Jeffries. "Don't believe the Hype”: Debunking the Panther Mythology. as found in Jones, Charles. The Black Panther Party Reconsidered. p. 44.

${ }^{11}$ Mao Tsetung. Analysis of the Classes in Chinese Society. as found in The Selected Works of Mao Tsetung, volume I. p. 19.

${ }^{12}$ To Die for the People. p. 49.
} 
Newton did not claim to have the answers to the many problems that existed for oppressed people, but he was committed to helping them find the answers.

Newton went door-to-door to find out what the residents needed to sustain a better standard of living. After gathering this information, Newton oriented the Black Panther Party's goals to address the concerns conveyed to him by the people in the community. ${ }^{13}$

Engaging the community in this way served two purposes. It kept the vanguard in touch with the actual needs of the people. Further, it helped create trust between the vanguard and the people so that when the time was right true social change could take place.

Ultimately, Newton's aim was to change the "people's perception about power, to teach them the strategic method of resisting the power structure through educational programs and

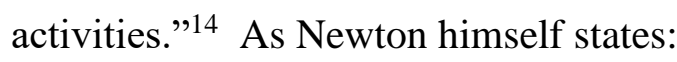

The main purpose of the vanguard group should be to raise the consciousness of the masses through educational programs and other activities. The sleeping masses must be bombarded with the correct approach to struggle and the party must use all means available to get this information across to the masses. ${ }^{15}$

However, Newton was quick to point out that the vanguard only exists through the support of the people and it can only get this support by serving the people's needs. Thus, with an emphasis on serving the people and engaging them in dialogue, Newton and the Black Panther Party created what Newton termed "survival programs," such as health clinics, breakfast programs, and the infamous police patrols. ${ }^{16}$ His point was to "lead the people by following their interests, with a view toward raising their consciousness to see beyond limited goals."17

Two issues regarding the survival programs should be made here. First, there is a pragmatic point that should not be overlooked. Certainly, the survival programs endeared the vanguard to the people and did create trust between the people and the vanguard. They also kept the revolutionary cadre close to the people and their actual lived needs. More importantly, they kept the lumpenproletariat alive so that when the time was right, real social action could take place. Newton viewed the survival programs as a life boat. If the people could not meet their

\footnotetext{
${ }^{13}$ Jeffries. p. 17.

${ }^{14}$ Ibid. p. 38.

${ }^{15}$ To Die for the People. p. 16.

${ }^{16}$ For a more in depth discussion of the Black Panther Party survival programs see, for example, Abron, JoNina. "Serving the People": The Survival Programs of the Black Panther Party. as found in The Black Panther Party Reconsidered. pp. 177-92.

17 To Die for the People. p. 50.
} 
own basic needs, then there would be no people to bring about revolution. The second point is theoretical. Because, for Newton, "revolution is a process" Newton left the Black Panther Party platform "open-ended so that it could develop and people could identify with it. [Newton] did not offer it to them as a conclusion, [it was offered] as a vehicle to move them to a higher level." 18

In the end the relationship between the vanguard and the people-specifically the lumpenproletariat - is an essential component of the revolutionary process for Newton. The vanguard "grows out of the conditions and needs of oppressed people," 19 and thus acts as both protector and mouth-piece. However, the vanguard also acts as educator of the people to help them become aware of the situation which is oppressing them and to point out the conditions which cause the problems that exist for them. Newton's unique contribution to the vanguardpeople dialectic was the institution of the survival programs which is a direct result of stepping away from intellectualizing and actually going to the people, "door-to-door", to find out what was important to them.

I will now briefly compare Newton's and Frantz Fanon's views of the lumpenproletariat. Then the "problem of lumpenization" - that is, the introduction of a criminal element into the Black Panther Party led to its demise — will be addressed.

Newton originally came to the idea that the lumpenproletariat could be radicalized from his exposure to Fanon. Fanon believed that " $[\mathrm{t}]$ he formation of a lumpenproletariat is a phenomenon which is governed by its own logic." 20 Newton agreed with Fanon on this count. The circumstance that gave rise to a lumpenproletariat class in Algeria was the movement of the peasantry into the more metropolitan areas. Thus, for Fanon, the lumpenproletariat class was strictly identified with this group of peasants.

On Newton's analysis, what gave rise to the lumpenproletariat class was two fold. It began with the movement of poor rural people to urban areas in search of jobs, as in the case of Algeria. However, in the United States, in the beginning, there were many proletarian jobs to be had. But, with advances in technologies and increased automation those jobs began to disappear. Therefore, while in Algeria a small peasant class was being pushed up into the sub-proletarian,

\footnotetext{
${ }^{18}$ Ibid. p. 47.

${ }^{19}$ Ibid. p. 50.

${ }^{20}$ Fanon, Frantz. The Wretched of the Earth. p. 81.
} 
that is lumpenproletariat, class, in the United States there were those being pushed up, but at the same time many in the proletariat class were being pushed downward. Further, for Newton the lumpenproletariat also included the underemployed and those employed in the service industry and other jobs that were not strictly proletarian or bourgeois. Thus, in the United States the lumpenproletariat was much larger and more centrally located in densely populated urban areas in the North and West.

Newton did agree with Fanon that "the pimps, the hooligans, the unemployed, and the petty criminals, when approached [would] give the liberation struggle all they have got, devoting themselves to the cause like valiant workers." 21 But again, Newton had more people in mind than simply pimps and petty criminals.

The greatest difference between Fanon and Newton results from the very different circumstances in which each found himself. For Fanon, "[t]he nationalist parties' propaganda always finds a response among the [lumpenproletariat]. The memory of the pre-colonial period is still very much alive." 22 Since in Fanon's case there was a collective remembrance of a time before the French occupation, those sympathies could be relied on to mobilize the lumpenproletariat. However, in the United States, there was no idealized past, especially for African-Americans, that could be appealed to. Therefore, for Newton, a future free from oppression was appealed to, on the one hand, while, on the other hand, a rearticulation of past wrongs continually reminded the underclass that they really did have nothing to lose.

I will now turn to an analysis of, and answer to, the Problem of Lumpenization in the Black Panther Party. On the face of it, the problem of lumpenization in the Black Panther Party is a simple statement of sociological fact that "the influence of [those] closely aligned with the criminal element created a crisis, one that would contribute to the demise of the organization."23 Chris Booker is the writer who most explicitly analyzes the problem of lumpenization. However, many have tried to dismiss Newton and the Black Panther Party by identifying them as criminals. Hugh Pearson's book, The Shadow of the Panther, for example is implicitly based on the linking of Newton and the Black Panther Party with criminality. While it may be the case that the introduction of a criminal element into the Party did lead to a crisis, too much emphasis

\footnotetext{
${ }^{21}$ Ibid. p. 81-2.

${ }^{22}$ Ibid. p. 69.

${ }^{23}$ Booker, Chris. Lumpenization: A Critical Error of The Black Panther Party. as found in Jones. p. 357.
} 
on this point leads to deeper theoretical and conceptual issues. For clarity, I will refer to the theoretical and conceptual aspects of the problem of lumpenization as the theory of lumpenization. The theory of lumpenization rests on two critical errors or misrepresentations. Before discussing the two errors on which the theory of lumpenization rests it should be made clear what it means that the theory of lumpenization is a conceptual problem. As a conceptual problem, the theory of lumpenization tries to frame, intentionally or not, any discussion of Newton or the Black Panther Party by introducing the idea that Newton and the Black Panther Party were basically just thugs and criminals. Of course, intimating that Newton and the other Panthers are criminals is just a rhetorical device to "poison the well" so that any further discussion skews one's understanding of what Newton had to say.

The first error is that those who put forward the theory of lumpenization are equating Marx's notion of the lumpenproletariat and Newton's understanding of the lumpenproletariat. The lumpenproletariat class, for Newton, is not synonymous with a criminal class. Newton's understanding was much broader including not only some petty criminals but also the unemployed, underemployed and those in the service industry. Thus the theory of lumpenization conveniently sidesteps Newton's insight that revolutionary potential no longer resided with the proletariat, and most likely results from trying to avoid directly dealing with what Newton truly had to say.

The second error on which the theory of lumpenization rests is that it misconstrues who the Black Panther Party was, and what the Black Panther Party was trying to do. The second error is closely associated with the first error of equivocation. Therefore, to claim that "one important lesson gleaned from the experience of the Black Panther Party is that organizations that seek to focus their recruitment on the lumpen should have effective mechanisms to reform new members," 24 is in actual fact quite inaccurate. One might be able to claim that the introduction of a criminal element can lead to problems within an organization. However, the Black Panther Party "always drew members from a broad cross-section of the African American community" 25 including "college students, persons from middle-class backgrounds, [and] working people."26 The accusation of lumpenization dismisses these members and implies

\footnotetext{
24 Ibid.

25 Jones. p. 46.

${ }^{26}$ Booker. p. 357.
} 
criminality on their part. Thus, again, the theory of lumpenization causes one to dismiss, uncritically, any insights or contributions Newton and the Black Panther Party might have.

Ultimately, the so-called problem of lumpenization is no problem at all, when understood conceptually. Most importantly, the theory of lumpenization fails to appreciate Newton's understanding and reinterpretation of class structure and Marxism. By equating Newton's use of lumpenproletariat with Marx's use, one can easily dismiss any contribution Newton and the Black Panther Party might have by classifying them all as thugs. Further, by identifying the lumpenproletariat solely with a criminal element one fails to appreciate the diversity that in fact existed within the Black Panther Party. This is not to deny, however, that a criminal element might have led to problems within the Black Panther Party - the sociological issue - but the close association of a criminal class with the lumpenproletariat is unwarranted - the conceptual issue.

To conclude, the purpose of this paper was to introduce some of Newton's important political insights. Newton read widely, and his gifts as an intellectual were most apparent when he reinterpreted and synthesized others' insights and made them relevant to the situation in which he found himself.

One of Newton's most important reinterpretations was the radicalization of the lumpenproletariat. Newton originally got the idea of the lumpenproletariat as the class with the most revolutionary potential from his exposure to Frantz Fanon. However, Newton broadened this class to not only include a "peasantry" that had moved to urban centers but also those who were unemployed and underemployed, that is the former proletariat.

Finally, it was noted that Newton's understanding of the lumpenproletariat was supposed to have led to the eventual downfall of the Black Panther Party. This was identified as the problem of lumpenization. The problem of lumpenization could be understood either as a sociological issue in which the introduction of a criminal element into the Black Panther Party led to a crisis. However, the problem of lumpenization can also be understood conceptually. It was shown that the theory of lumpenization arises due in part to a lack of understanding of how Newton is using the term lumpenproletariat. Ultimately, the theory of lumpenization leads to an uncharitable reading of Newton, and leads to the easy dismissal of insights Newton does have. 